\title{
Factors Affecting the Satisfaction of Post-Disaster \\ Resettlers in the Long Term: A Case Study on the Resettlement Sites of Tsunami-Affected Communities in Sri Lanka
}

\author{
Jagath Manatunge (Corresponding author) \\ Dept. of Civil Engineering, University of Moratuwa \\ Katubedda, Moratuwa, Sri Lanka
}

Tel: 94-112-65567Ｅ-mail: manatunge@uom.lk

Udya Abeysinghe

Dept. of Civil Engineering, University of Moratuwa

Katubedda, Moratuwa, Sri Lanka

Tel: 94-112-65567Ｅ-mail: udya.abeysinghe@gmail.com

Received: January 10, 2017 Accepted: February 7, 2017 Published: February 28, 2017

doi:10.5296/jad.v3i1.10604 URL: http://dx.doi.org/10.5296/jad.v3i1.10604

\begin{abstract}
The 2004 tsunami is one of the most devastating natural disasters the world has experienced in the recent past, and it is imperative that we learn from this experience about how to effectively implement post-disaster housing projects. Relatively little research has been conducted to study the level of satisfaction of affected persons in the long term after receiving houses in new settlements with 'better' socio-economic and physical facilities. The post-disaster resettlement schemes established in Sri Lanka provide an ideal setting to study the factors affecting long-term satisfaction of communities in the context of providing permanent housing. The present study focused on 12 such sites in Sri Lanka. The elements/criteria chosen to assess the long-term satisfaction of the resettlers consisted of factors related to site selection, the design of dwelling units and surroundings, material well-being and provision of services and infrastructure, aspects related to social factors and perceptions regarding the resettlement process, neighbourhood and social interactions. From
\end{abstract}




\section{Macrothink

the observations of this study, it can be concluded that despite the availability of sufficient funding, the opportunities to plan, design and implement sustainable community-responsive resettlement programmes for tsunami affected households were largely missed. Overall, it was noted that the resettled communities included in the present study are not satisfied in the long-term due to various physical, environmental and socio-economic factors. Particularly inappropriate site selection and design of functional spaces, poor construction of houses and common spaces, and inconvenient access to social infrastructure assets were factors that need more attention in planning resettlement housing.

Keywords: Beneficiary participation, housing reconstruction, planning and implementation, site selection 


\section{Introduction}

A disaster occurs when an extreme event exceeds a community's ability to cope with that event (FEMA, 2017). Vulnerable communities are more severely affected due to disasters causing substantial property damage, disruption of services and day-to-day activities including livelihoods and possible casualties, which leave the affected communities unable to function normally without outside assistance (Benson \& Twigg, 2007). The physical impacts of a disaster are the most obvious and easy to quantify; however, the social consequences, which include psychosocial, demographic, economic, and political implications, can develop over an extended period and are difficult to assess when they occur (FEMA, 2017). Usually, the social consequences are caused as a direct result of the physical damage/loss of property. Possibly the most noteworthy physical impact of a disaster on the affected community would be the loss of housing units, which eventually will result in severe social consequences. Despite the difficulty in responding to and counteracting these social impacts, it is nonetheless important to compensate the affected communities for their material losses, especially housing, because such initiatives, if well-planned, can successfully contribute to the long process of disaster recovery.

Significant challenges such as lack of access to previously settled land, logistical issues in planning and delivery and scarcity of resources may arise in post-disaster reconstruction efforts, particularly those following large-scale disasters (Davidson et al., 2007; Duyne Barenstein, 2012; Ophiyandri, 2011). Efforts of reconstruction may be further hampered by factors such as institutional bureaucracy, malpractices and corruption, lack of coordination, scarcity of experienced construction personnel and pressures from government other stakeholders for faster project completion (Duyne Barenstein, 2012; Ophiyandri, 2011). There are certain crucial factors that continue to cause housing reconstruction projects to fail with the targeted beneficiaries modifying or outright rejecting the housing provided for them. In certain cases, they may opt for selling or renting the houses. Such issues include, lack of community participation in planning of resettlement housing, lack of communication, unplanned resettlement process and the cultural appropriateness of recovery measures and have been a recurring challenge (Delany \& Shrader, 2000; Miyata \& Manatunge, 2004; Barakat, 2003; Bilau et al., 2015). All of these challenges must be adequately managed to have a successful reconstruction programme (Bilau et al., 2015).

There are two modes of resettlement housing delivery: provision of assistance to rebuild original housing units, often with the active participation of householders in the building process; and permanent relocation to resettlement schemes (Shaw \& Ahmed, 2010). The advantages of reconstructing houses on their original sites include the provision of greater control of the design and construction process to the householder and minimization of disruption to community networks, relationships and livelihoods. Also, it avoids the costs and complexities associated with acquiring suitable resettlement sites (Shaw \& Ahmed, 2010). However, rebuilding the original dwellings is not possible if the affected communities are settled elsewhere at locations which are deemed safer for human settlements. When in-situ rebuilding is the preferred option, different resettlement options may be required to mitigate future hazards or implement alternative land use policies (Birkmann, \& Fernando, 2008; 
Shaw \& Ahmed, 2010). When the affected communities are resettled involuntarily, proper planning is important to lessen future vulnerabilities and to improve long-term sustainability. Over the decades, there has been growing concern about the negative consequences of involuntary displacement, many of which can be mitigated by meticulous planning and by providing resettlers with proper compensation (Manatunge \& Takesada, $2013 \mathrm{a}$, b; Takesada et al., 2008). As a consequence, resettlement of the affected communities has been a subject discussed focusing on various impacts, with particular attention paid to dissatisfaction among on re-settlers mainly due to hardships that they face at new settlements. Many studies related to resettlement projects regularly highlight the difficulties that the affected communities face and the dissatisfaction of persons that transpire as a result of changes in the places they live and the livelihoods (Takesada et al., 2008; Manatunge \& Takesada, 2013 a, b). Although from the perspective of affected people, resettlement in new locations is always an undesirable affair; the implementing agencies often assume that the resettlement schemes that they propose are often successful. Therefore, it is imperative that these two extremes are reconciled by learning from the past, so as to minimise such adverse effects occurring in the future. Reconstruction strategies should be implemented after studying the perceptions and the needs of affected people. There is a possibility that the newly constructed facilities become unacceptable from the day the construction is complete if proper attention is not paid to the needs of affected people (Kusky, 2003; Miyata \& Manatunge, 2004). This will make sure that they are sufficiently satisfied after relocation. The primary focus of this study, therefore, is about the Sri Lankan experience of involuntary resettlement of affected communities aftermath of 2004 tsunami, drawing attention to factors that affected their long-term satisfaction.

The 2004 tsunami resulted in the most wide-ranging natural disaster the world has seen. The disaster severely affected several different countries in Asia. It is important that we learn as much as we can from this experience about how to effectively plan and implement post-disaster housing schemes. In Sri Lanka, the 2004 tsunami impacted nearly $65 \%$ of the coastline (nearly $1,000 \mathrm{~km}$ ) from the north to the south-west. However, the impacts varied depending on coastal landforms, beach slope and the occurrence of natural features that could mitigate the impacts. About 65,000 houses were damaged as a result of the tsunami, and relocation of these affected families was the priority of post-disaster recovery efforts. Needs assessment presented to the donors identified damages to housing as the single largest component of damage to physical assets. Subsequent field studies conducted by many stakeholder organisations have shown that post-disaster housing is viewed by the affected households as their primary concern and the need, and regaining an acceptable permanent shelter is their priority goal (ADB, 2005).

There were no pre-existing policy frameworks or institutional framework in Sri Lanka that could be readily adopted to deal with the situation aftermath of the 2004 tsunami. Soon after the tsunami, a buffer zone along the coast was established, and the government decided to resettle the communities that lived within this coastal buffer zone (Note: The Government later abandoned this buffer zone policy - See Jayasuriya et al., 2006 for a detailed discussion on the post-tsunami recovery in Sri Lanka, and the buffer zone policy). Coordination among 
the stakeholders and communication issues were widespread, and the allocation of responsibilities was not clear (Mulligan \& Shaw, 2007). Insufficient community participation in site selection, planning and implementation were notable from the inception (UoM, 2006). Alternative livelihood options were not adequately considered for communities who were forced to resettle further inland (Shaw \& Ahmed, 2010). In addition to this, scarcity of land for relocation, anomalies in the initial housing needs assessment with conflicting statistics from different government agencies, capacity constraints including a lack of expertise on the part of implementing agencies and pressure for swift implementation (Mulligan \& Shaw, 2007; Bilau et al., 2015). The policy shifts and lack of reliable data affecting housing targets and reconstruction plans led to systemic confusion and, ultimately, reconstruction delays (Uyangoda, 2005; Grewal, 2006). Human suffering has been exacerbated by delays, inequities and inefficiencies in housing and livelihood rehabilitation processes which have increased poverty and threatened social stability (Bilau et al., 2015).

In the short run the dispossession and displacement of people from their assets, resources, established livelihoods, incomes and sociological relationships presents complex risks and could potentially lead to severe hardships, physically, socially and mentally. There are many studies, largely socio-anthropological investigations, which demonstrate the immediate effects of the resettlement. In contrast, relatively little research has been conducted on the short- and long-term levels of satisfaction that the resettlers derive after accepting the new assets in new environments with "better" socio-economic and physical facilities. This is an area that merits careful examination. In this regard, a hypothesis worth testing is that the negative short-term consequences of involuntary displacement are offset by the longer term benefits generated from enhanced socio-economic opportunities created in the newly developed relocation site (Manatunge eta al., 2001; Miyata \& Manatunge, 2004; Manatunge, et al., $2013 \mathrm{a}, \mathrm{b})$.

The post-disaster resettlement schemes that were established in Sri Lanka after the 2004 tsunami provide an ideal setting for testing the preceding hypothesis. The present study is aimed at studying the satisfaction levels of the beneficiaries of tsunami resentment housing with regard to physical, social and environmental factors prevalent in the resettlement sites. A study along these lines would complement existing relocation studies by providing a realistic evaluation of factors that need proper attention during planning, designing and implementation of resettlement schemes to ensure that the beneficiaries are ultimately satisfied by what they have received as compensation. More than a decade after the 2004 tsunami, the resettlement projects in Sri Lanka provide valuable lessons which can be used to devise better plans for the design and delivery and the aspects that should be promoted or avoided to make the resettlers satisfied, in post-disaster resettlement programmes.

\section{Methodology}

\subsection{Selection of Study Sites}

The government formed two institutions to coordinate the resettlement housing programmes: (i) the Tsunami Housing and Resettlement Unit (THRU) in the Ministry of Urban Development and Water Supply, and (ii) Task Force for Rebuilding the Nation (TAFREN). 
These two institutions were dissolved and the Reconstruction and Development Agency (RADA) was created in November 2005. Subsequently, two housing assistance schemes were proposed accommodating the requirements of the coastal buffer zone plan: (i) 'owner-driven program', which provided funds to the householders to rebuild or repair houses in their previous settleemnts. This was applicable to housing units located inside the newly declared buffer zone which had sustained minor damage, and to affected houses located outside the bufffer zone, and (ii) 'donor-driven program' which provided houses to those who were residing within the buffer zone and to be resettled in new houses built by the donor agencies.

Donors who were interested in constructing resettlement schemes were invited to register with the TAFREN (or its successor the RADA) and submit proposals identifying the number of houses they wished to build and the targeted districts. The donors were required to comply with three Guidelines:

(i) The Implementation Guidelines for Donor Assisted Housing and Township Reconstruction, which was formulated by TAFREN (RADA, 2007)

(ii) The Guidelines for Housing Development in Coastal Sri Lanka: Statutory Requirements and Best-Practice Guide to Settlement Planning, Housing Design and Service Provision with Special Emphasis on Disaster Preparedness, which was prepared by the National Housing Development Authority (NHDA, 2005)

(iii) Building Planning Guidelines of the Urban Development Authority

Once selected, the government delegated the responsibility of construction of resettlement housing schemes to donors while the responsibility was retained with the THRU for site selection, land acquisition, formulation of design guidelines, approvals, subsequent inspection of construction work, provision of services (electricity, water supply and sanitation) up to the site boundaries. The final approval for beneficiary eligibility was given by the THRU. By the middle of 2005, the THRU had finalised plans to build 485 housing projects in 11 districts in Sri Lanka.

In the year 2006, a comprehensive survey was conducted by the University of Moratuwa, Sri Lanka (UoM), titled, Rapid Environmental Assessment (REA) on Tsunami Permanent Housing Sites in Sri Lanka, which covered 409 sites (the rest of the sites were not finalised by the time the study was conducted). The study used an environmental checklist for assessing the suitability of sites for post-tsunami housing construction, which covered physical, social and biological/ecological features of the sites. The study was carried out to identify and understand the nature and magnitude of environmental issues and to make necessary recommendations as mitigatory measures and to establish a spatial database that will enable long-term monitoring to ensure minimum adverse environmental impacts (UoM, 2006).

Out of the 205 housing projects implemented in the Galle, Matara and Hambantota districts, 12 sites were selected for the present study. First, the sites were screened based on two criteria: (i) projects which have 20 or more houses (the UDA Planning Guidelines are only applicable when the project consists of more than 20 housing units), and (ii) only the projects implemented under the donor-driven program were selected for the study to avoid any 
impacts due to different modes of implementation (as opposed to owner-driven projects) on the outcomes of resettlement (Ratnayake \& Rameezdeen, 2008; Thiruppugazh, 2011; Duyne Barenstein, 2012).

After the first screening, the database of the REA conducted by the University of Moratuwa was used adopting random stratified sampling technique to select the candidate sites for this study. The sites were divided into three strata denoted by those having significant, moderate and minor/no impacts based on the observations of the REA and adopting an evaluation criterion developed after a series of brainstorming discussions involving a panel of experts participated in the preparation of the REA (UoM, 2006), and subsequently 12 sites were selected for the present study, four sites each from the three districts (Table 1, Figure 1).

\subsection{Data collection}

The purpose of this study is to establish the factors that affect the long-term satisfaction of resettlers of post-tsunami permanent housing, focusing on 12 selected sites in Sri Lanka (Table 1). The nature of this research demands comprehensive evaluation of factors affecting the long-term satisfaction of post-tsunami resettlements. Comprehensive, semi-structured interviews with key informants and in-depth field surveys targeted at recipients of houses were used as the main data collection technique. As part of the methodology, questionnaires were prepared to understand the factors/indicators that are supposed to contribute to the long-term (more than a decade) satisfaction among the resettled communities (or lack of satisfaction).

The data collection was done in three stages:

(i) The interviews for the first phase were conducted with key informants (officers of the UDA, Grama Niladharis (Village Administrative Officer), community leaders, etc.) to understand the implementation process of the projects, involvement of various stakeholders at different stages of implementation, and any strategies adopted to solve the impacts identified during the REA so as to ensure long-term satisfaction of the communities who were resettled. More than 20 such in-depth interviews were conducted covering all the three districts. For each site, the following data were also collected during these meetings:
a. Ownership of the houses - original owner, or subsequent transfer of ownership
b. Number of abandoned houses

(ii) focus group discussions (with groups of resettled households): Information was also gathered by having group discussions with persons who resided in the resettled villages and the vicinity (not necessarily project- affected persons). These groups/individuals were instrumental in providing information as affected persons and/or third parties, and their opinions were carefully filtered and used for preparing the questionnaire for phase iii, and subsequently for cross-checking the data collected during the survey. Seventeen such interviews were conducted (at least one interview for each site), and the individuals for each group were casually invited through informal community leaders, to represent 
different viewpoints. Local communities took an interest in the research while conducting these discussions and it was common for them to join in. Where several neighbours were present, these focus group meetings were conducted as community meetings which discussed their key concerns in detail, thereby widening the range of perspectives available for the study.

(iii) the detailed household survey: Household surveys were carried out in 2016 covering the 12 resettlement site (see Figure 1). Data and information were collected by way of physical inspections, observations done at each site and interviews conducted with beneficiaries using a structured questionnaire. Between 10 and 15 households were interviewed at each location that were selected randomly from different locations of the site (representing topographical differences and distance to the main access road, etc.).

As a study that involves a post-project review of resettlement schemes for involuntarily displaced persons, the assessment of impacts can be complicated. The criteria and/or elements selected to represent key considerations and to identify the strengths and/or weaknesses of the resettlement scheme should be appropriate enough to identify and assess the negative/positive impact and to propose preventive/mitigation measures. The elements/criteria included in the questionnaire to assess the long-term satisfaction of the resettlers were based on past studies (Manatunge et al., 2001; Oliver-Smith, 2001, RADA, 2007, UoM, 2006, Ratnayake \& Rameezdeen, 2008, Shaw \& Ahmed, 2010, Perera et al., 2013, Dias et al., 2016), preliminary site visits and experts discussions. Also, the provisions of the TAFREN, NHDA and UDA Guidelines were also used in the formulation of questions.

The questionnaire that was prepared consisted of the following aspects (Table 2):

1. Biographical and personal attributes of respondents.

2. Economic activities used to measure the level of satisfaction.

3. Respondents' satisfaction of factors related to the physical environment or material well-being and services.

4. Questions to measure satisfaction related to social factors and perceptions regarding the resettlement process, aspects of the neighbourhood, social interactions, infrastructure provisions. 


\section{Macrothink}

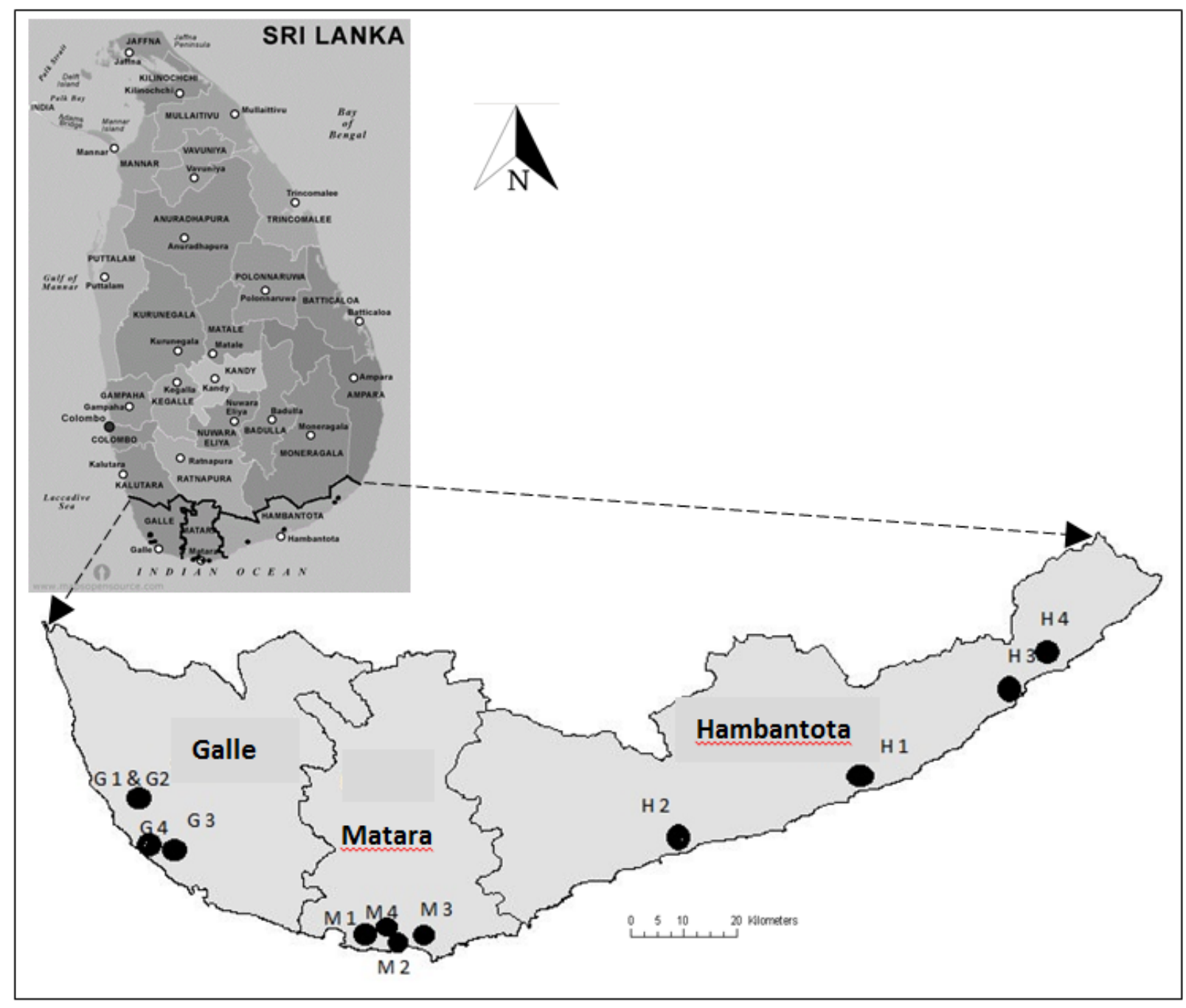

Figure 1. The location of sites selected for the study

By the questionnaire survey, level of satisfaction of the beneficiaries after a decade of the tsunami disaster was measured with what they have received in respect of the environment and social infrastructure and associated facilities. In this questionnaire, interviewees were asked to rate the level of satisfaction of different environmental and social variables based on a typical five-level Likert scale (1 - Strongly dissatisfied, 2 - Dissatisfied, 3 - Neutral, 4 Satisfied, 5 - Strongly satisfied).

Following Manatunge et al. (2013 a, b), 'satisfaction' in this study refers to the perception of the affected persons with respect to the satisfaction that they derive as a result of receiving houses, physical and social infrastructure, new opportunities (occupational and livelihood-related), other social and environmental factors, etc. The structure of the questionnaire presented above, and Table 2 provides the elements to which the level of satisfaction was related to. 


\section{Macrothink}

Table 1. Selected sites of each District, Site Notation and number of houses of each site

\begin{tabular}{|c|c|c|c|c|c|}
\hline District & $\begin{array}{c}\text { Site } \\
\text { Notation }\end{array}$ & Name of the Site & $\begin{array}{c}\text { Divisional Secretariat } \\
\text { Division }^{1}\end{array}$ & $\begin{array}{c}\text { Grama Niladari } \\
\text { Division }^{2}\end{array}$ & $\begin{array}{l}\text { Number } \\
\text { of houses }\end{array}$ \\
\hline \multirow{4}{*}{ 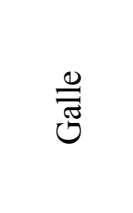 } & G1 & Walahanduwawaththa & Akmeemana & Meegoda & 27 \\
\hline & $\mathrm{G} 2$ & Karanketiya & Akmeemana & Pilana & 120 \\
\hline & G3 & Eluwila & Habaraduwa & Talpe & 45 \\
\hline & G4 & Kesbepana & Habaraduwa & Unawatuna Central & 51 \\
\hline \multirow{5}{*}{ 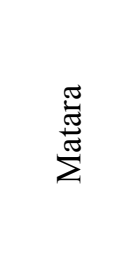 } & M1 & Pengiriwaththa, & Matara & Rassandeniya & 50 \\
\hline & & Rassandeniya & & & \\
\hline & M2 & Kandagodella & Devinuwara & Gandara West & 24 \\
\hline & M3 & Minikirula & Dickwella & & 20 \\
\hline & M4 & Nupawela Flats & Matara & Nupe & 64 \\
\hline \multirow{4}{*}{ 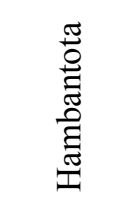 } & H1 & Mayurapura & Hambantota & & 79 \\
\hline & $\mathrm{H} 2$ & Wellodaya & Tangalle & Wellodaya & 51 \\
\hline & $\mathrm{H} 3$ & Kirinda New Town & Tissamaharama & Kirinda & 100 \\
\hline & $\mathrm{H} 4$ & Nidangalawella & Tissamaharama & Kirinda & 34 \\
\hline
\end{tabular}

${ }^{1,2}$ Divisional Secretariat Division and Grama Niladhai Division are administrative units in Sri Lanka, the latter being the smallest administrative division of the country. A number of Grama Niladhari Divisions will form a Divisional Secretariat, which is a sub-unit of a District.

Surveys conducted to determine the degree of satisfaction about resettlement planning and physical benefits received (i.e., such as the resettlement benefits in this study) are complicated for two reasons. First, an individual's level of satisfaction is very subjective and depends on personal qualities as well as having a temporal dimension - it could change with the progressive increase or decrease of their economic level. Second, interviewees tend not to disclose their true feelings with the assumption that expressing satisfaction would lead to a series of questions asking for an explanation. They tend to skip such issues or sometimes provide unclear or incomplete answers, at times even contradicting their other responses. 


\section{Macrothink}

Journal of Asian Development

ISSN 2377-9594

2017, Vol. 3, No. 1

Table 2. Environmental and Social variables used to ascertain the level of satisfaction of beneficiaries

\section{A. Environmental Criteria}

\section{A1. Dwelling:}

Size of the dwelling unit

Interior design

Lighting and ventilation

Building quality

Noise

Fire and other safety measures

Level of completion of the house

A2. Surrounding Environment:

Landscaping

Site Selection

Layout of the property

A3. Services:

Water supply

Electricity

Solid waste management

Wastewater management

\section{B. Social Criteria}

\section{B1. Neighbourhood:}

Leisure and sport facilities

Neighbourhood safety

B2. Infrastructure Facilities and other:

Hospital facilities

Education facilities

Shopping and other daily facilities

Public transport

Parking space

Facilities for religious practices

Convenience to Livelihood

Land tenure

Distance to public offices

Time for family commitments

Privacy

Community development plans

Beneficiary participation in planning

Conflicts and Social Issues

Following Manatunge et al. (2013 a, b) and their alternative approach to posing direct questions to assess satisfaction, this survey interviewed households by formulating indirect questions that were included in the questionnaire that would gain insight into their attitudes by relating their experiences to hypothetical situations such their willingness to sell or rent the house (which reflects their lesser attachment to the location), or their choice to choose between the present site or whether to return to the original place or any other place.

\section{Results}

\subsection{Background of the Resettlers of the Selected Sites}

The ethnicity of almost all the respondents of Galle and Matara Districts were Sinhalese, of whom the majority (more than 85\%) were Buddhists, whereas in the Hambantota District, about $67 \%$ were Sinhalese/Buddhists, and the rest were Muslim people. The majority of the households are fishermen in Matara and Hambantota sites, and there is a notable proportion of households who are employed in the private sector (Table 3). 


\section{Macrothink}

Table 3. Employment composition of the households in the sites selected for the survey

\begin{tabular}{llll}
\hline & Galle & Matara & Hambantota \\
\hline Fishing and fishery-related & $30.0 \%$ & $53.0 \%$ & $61.0 \%$ \\
Private Sector & $34.0 \%$ & $22.0 \%$ & $24.0 \%$ \\
Public Sector & $25.0 \%$ & $20.0 \%$ & $2.0 \%$ \\
Self-employment and other & $11.0 \%$ & $5.0 \%$ & $13.0 \%$ \\
\hline
\end{tabular}

Average household sizes of the sites included in the present study in Galle, Matara and Hambantota, were 4.6, 4.7 and 4.2, respectively.

\subsection{Current status with regard to occupation of houses}

Abandoned houses: During the field visits, it was noted that several houses have already been abandoned. In the Galle District, all the sites had abandoned houses, which ranged from 4\% 10\% (Figure 2). Two sites at Matara had no abandoned houses (Sites M1 and M4), and one site at Hambantota (Site H3) had no abandoned sites. However, there were more than $12 \%$ of the houses been abandoned in site M2, and more than $20 \%$ at site $\mathrm{H} 1$ and almost $50 \%$ of the houses have been abandoned at $\mathrm{H} 4$.

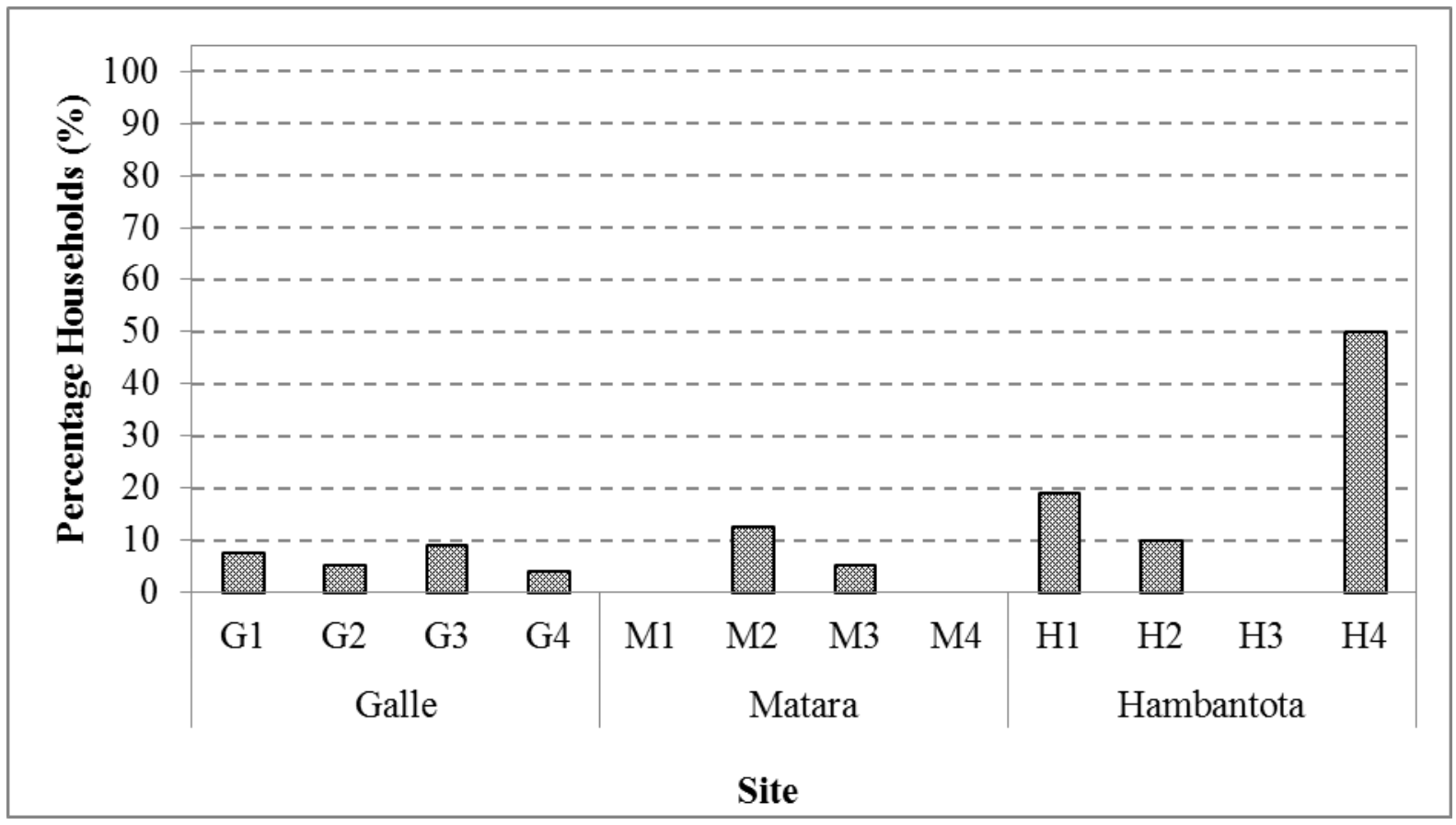

Figure 2. Percentage of houses that have been abandoned by the beneficiaries 


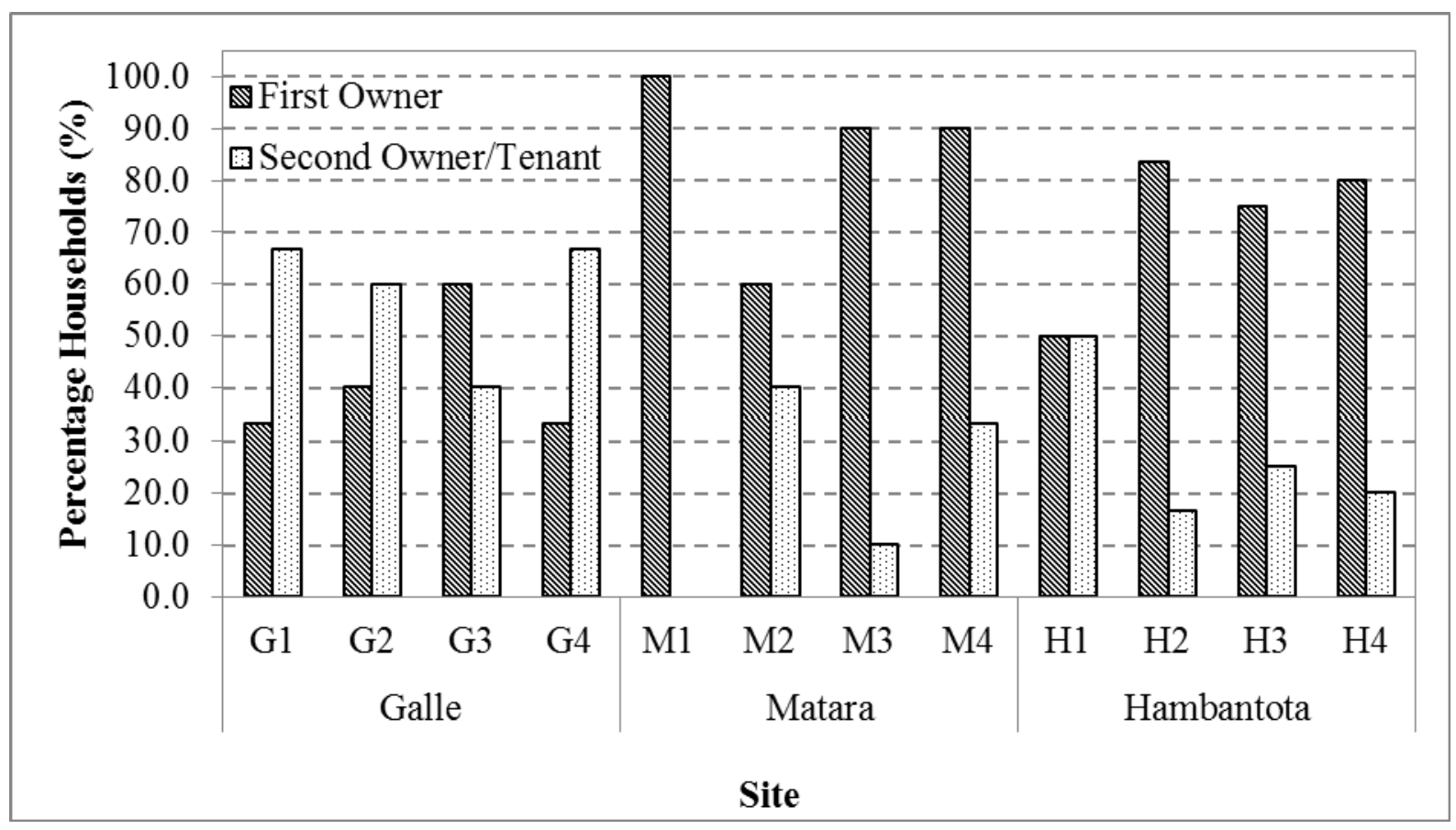

Figure 3. Percentage houses occupied by the original resettlers and occupied by others

Ownership of houses: It was observed that some of the beneficiaries of the resettlement programme (referred to as the first owners) either have sold the houses already or have rented the houses (Figure 3). This observation was notable in the Galle District sites where more than $60 \%$ of the houses in three sites (G1, G2 and G4) and more than $40 \%$ of the houses on the other site (G3) were not occupied by the beneficiaries. In contrast to this, the majority of the houses in Matara and Hambantota sites were still occupied by the first owners. At one site in Matara (site M1), almost all the houses were occupied by the first owners, and two other sites (M3 and M4) had more than $90 \%$ of the houses occupied by them. Hambantota sites too had three sites $(\mathrm{H} 2, \mathrm{H} 3$ and $\mathrm{H} 4)$ where more than $80 \%$ of the houses occupied by the original settlers.

Houses already sold or rented and owners who are willing to sell or rent: Percentage of households who are willing to sell or rent is quietly different to the percentage of houses already sold or rented. As discussed above, about $40-60 \%$ the beneficiaries in the Galle sites have already sold the houses or rented out (Figure 3). Moreover, it was noted that some of the beneficiaries who still occupy these houses are willing to sell the houses or rent them (Figure 4). About 30\% of the first owners are willing to sell/rent the houses in Galle (G2 and G3). In Matara, the majority of the households at sites M1 and M4 showed a willingness to sell/rent their houses, despite the fact that almost all the houses at M1 are still occupied by original settlers. At Hambantota too, more than $70 \%$ of the households at two sites $(\mathrm{H} 2$ and $\mathrm{H} 4)$ showed their willingness to sell/rent the houses. 


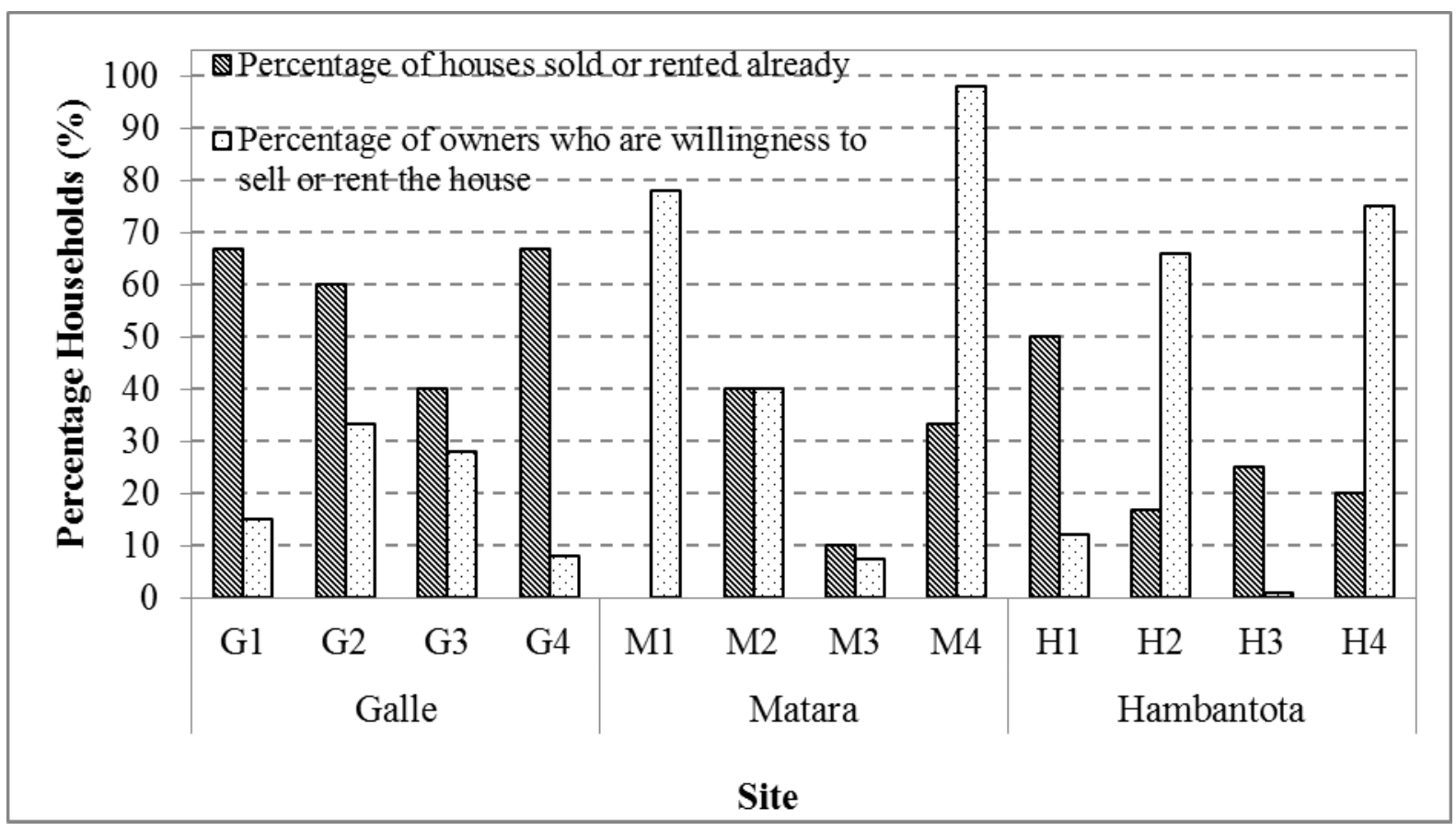

Figure 4. Percentage of household who are willing to sell/rent the houses

The percentages of houses sold or rented out already are directly related to the land tenure and the demand for the houses or land plots. As shown in Figures 3 and 4, Galle district sites showed the highest percentage of houses sold or rented out. The resettlers of the sites G1, G2 and G4, were given legal ownership of their land plots. For site G3 of the Galle District, only part of the resettlers was offered legal ownership for their land. In contrast, in the Matara and Hambantota Districts, most of the resettlers did not hold the legal deeds for their land plots. Therefore they have not been able to sell or rent the houses. In the Matara district, most of the resettlement sites are located within or close to urban areas where the demand for land and hence the land prices are very high. The willingness to sell or rent the houses is Matara is high, due to strong demand for housing, especially at sites M1 and M4, both of which are conveniently located close to popular schools and the town centre. Even though they did not offer legal titles, some households have rented their houses, both at Matara and Hambantota. Hambantota is the least populated district in all the three districts, and land demand is very low compared to the other two. Average sizes of land plots received by the beneficiaries in Galle and Matara were $6-8$ perch whereas at Hambantota it was $15-20$ perch. Therefore, the beneficiaries even in the Hambantota District are willing to sell the land plots given that a market exists for relatively larger sized land plots, similar to the ones that the beneficiaries received. 


\subsection{Level of Satisfaction: Social Factors}

\subsubsection{Galle District}

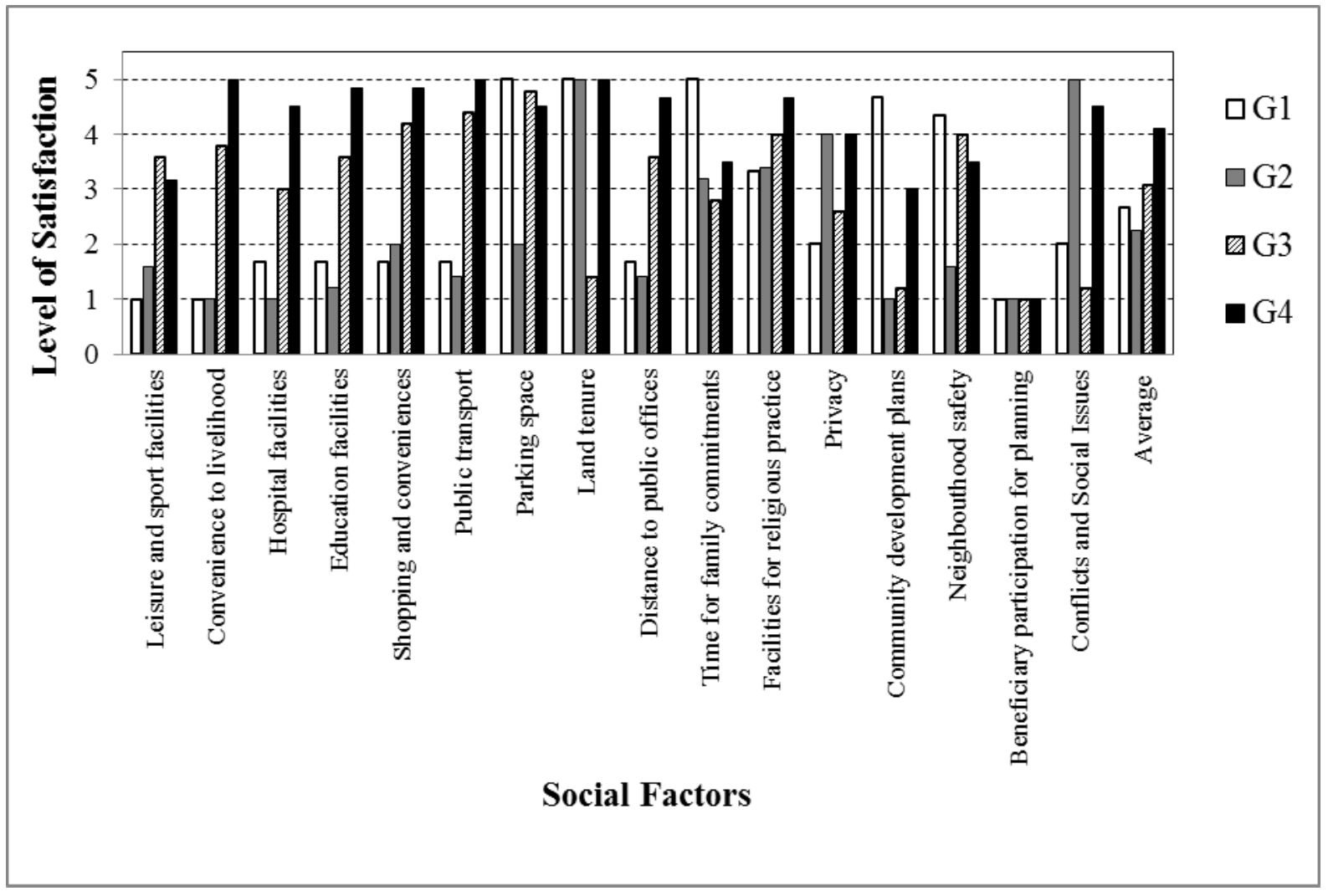

Figure 5. Level of satisfaction due to social factors in the Galle District

(Level of satisfaction: 1 - Strongly dissatisfied, 2 - Dissatisfied, 3 - Neutral, 4 - Satisfied, 5 - Strongly satisfied)

When considering the level of satisfaction due to social factors, beneficiary participation in the planning of resettlement housing programmes was the only factor that depicted strong dissatisfaction (satisfaction level: 1) among all the respondents in all the four sites (Figure 5). Respondents of both G1 and G2 indicated strong dissatisfaction in connection with many social factors, such as leisure and sports facilities, hospital and education facilities, shopping and conveniences, public transport, average distance to public officers, community development programs for resettlers and convenience to livelihood. Both these sites are located in rural areas (nearly $30 \mathrm{~min}$ travel distance by public transport to nearest town). For both the locations, there is only bus providing transport services to the community, which makes two trips per day. Most of the resettlers in these sites are fishermen who lived close to the coastal belt before the tsunami disaster. At present, they have to make a struggle to continue their livelihood due to the need to travel. It takes at least two hours for the fishermen to reach the fishery harbour by bicycle or they need to hire three-wheelers, which is a costly affair. In addition to the inconvenience in reaching the harbour, they face further difficulties with regard to protecting their bicycles while they are away in the sea, and conversely 
protecting their fishing gear (which they leave behind in the boat landing sites together with the boat) while they are away at home. Correspondingly, the respondents were strongly dissatisfied of the resettlement programme due to these factors which adversely affect their livelihood and income generating activities. Site G3 and G4 are located relatively close to an urban area conveniently located near the main road connecting the city areas. The two sites are located close to the shore, most of the households, including fishers, are not facing any major difficulties in continuing their previous livelihoods. Therefore, the beneficiaries of houses in these two sites are either satisfied or strongly satisfied in connection with most of the social factors. Some of the respondents of site G3 expressed strong dissatisfaction because they have not received the legal titles for the land plots. Occupants of sites G3 and G4 are more or less satisfied as to the social factors than those in the other two sites, mainly due to the locational advantage of the sites: easy access to the city, hospital and education facilities, shopping and other conveniences, public transport and proximity to public offices.

Neighbourhood safety, privacy, conflicts and social issues were some of the factors that the respondents expressed their dissatisfaction. Most of the resettlers in site G2 expressed their strong dissatisfaction regarding neighbourhood safety, probably due to the site established within highly populated host communities, which some of the respondents perceived as hostile toward the resettlers. The majority of the resettlers, other than in site G1, were dissatisfied when privacy was considered as a factor, mainly due to the closeness of the houses to each other and not having boundary walls. The side distance between two houses, in site G2, is not more than a meter in most cases, the space between rear boundaries are also very limited.

The majority of the respondents in sites G1 and G3 reported that there are very frequent conflicts and social issues among the residents and therefore they are strongly dissatisfied of the existing settlements. It was observed that such conflicts and social problems among residents arise due to many reasons of which issues related to privacy was the most cited. Extramarital affairs, early marriages among the young, unsolicited associations among males both among the youth and adults, mainly for gambling, drug usage, etc.

According to the resettlers, beneficiaries' participation in planning programs has been totally ignored by planning and implementing agencies. Their strong dissatisfaction regarding this factor is reflected again in most of the environmental factors described below, as their needs, concerns and requirements went unnoticed during planning stages.

In the Matara District, the level of satisfaction was low in relation to factors such as leisure and sports facilities, neighbourhood safety, land tenure, privacy, beneficiaries' participation in planning and conflicts and social issues (Figure 6). 


\section{MInstitute ${ }^{\text {Mink }}$}

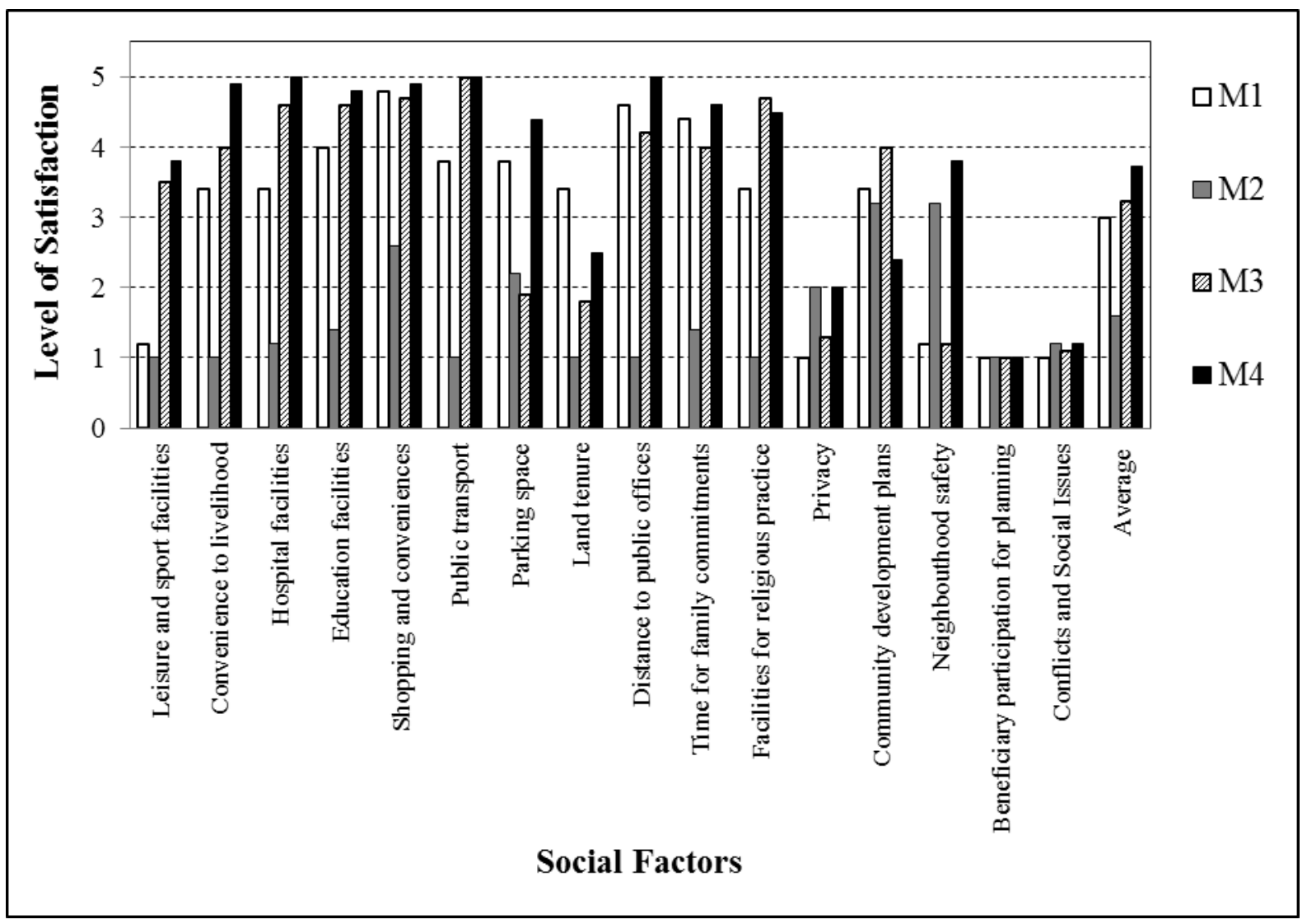

Figure 6. Level of satisfaction due to social factors in the Matara District

(Level of satisfaction: 1 - Strongly dissatisfied, 2 - Dissatisfied, 3 - Neutral, 4 - Satisfied, 5 - Strongly satisfied)

Almost all the respondents, similar to the observation in the sites in Galle, were highly dissatisfied due to lack of beneficiary participation during the planning stages and they attributed to most of the factors that they are dissatisfied with for that particular reason. Occupants of site M2 expressed their dissatisfaction as to most of the social factors, mostly attributable to its location in a hilly terrain. Even though the site is located near the main road, occupants experience difficulties in accessing the site. Beneficiaries of sites M3 and M4 are mostly satisfied or strongly satisfied with the as the sites are conveniently located with easy access to facilities, and with sufficient transport facilities. These two sites are located in the proximity to urban and suburban areas where there is easy access to facilities as mentioned above.

Privacy was again a major concern in the sites located in Matara. Almost all the respondents, similar to those in Galle, were dissatisfied with the orientation of the housing units, their relative locations which are very close to each other, which the occupants found to affect their privacy. As a consequence, conflicts and social issues were other factors that were mentioned by the respondents as one of the major concerns that there are living with high level of 


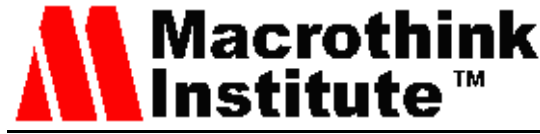

dissatisfaction. The land plots are small, and the houses are located very close to each other. The sites lack leisure and recreational facilities for the children and the youth. The reasons that cause social conflicts are the same as reported above for Galle sites.

\subsubsection{Hambantota District}

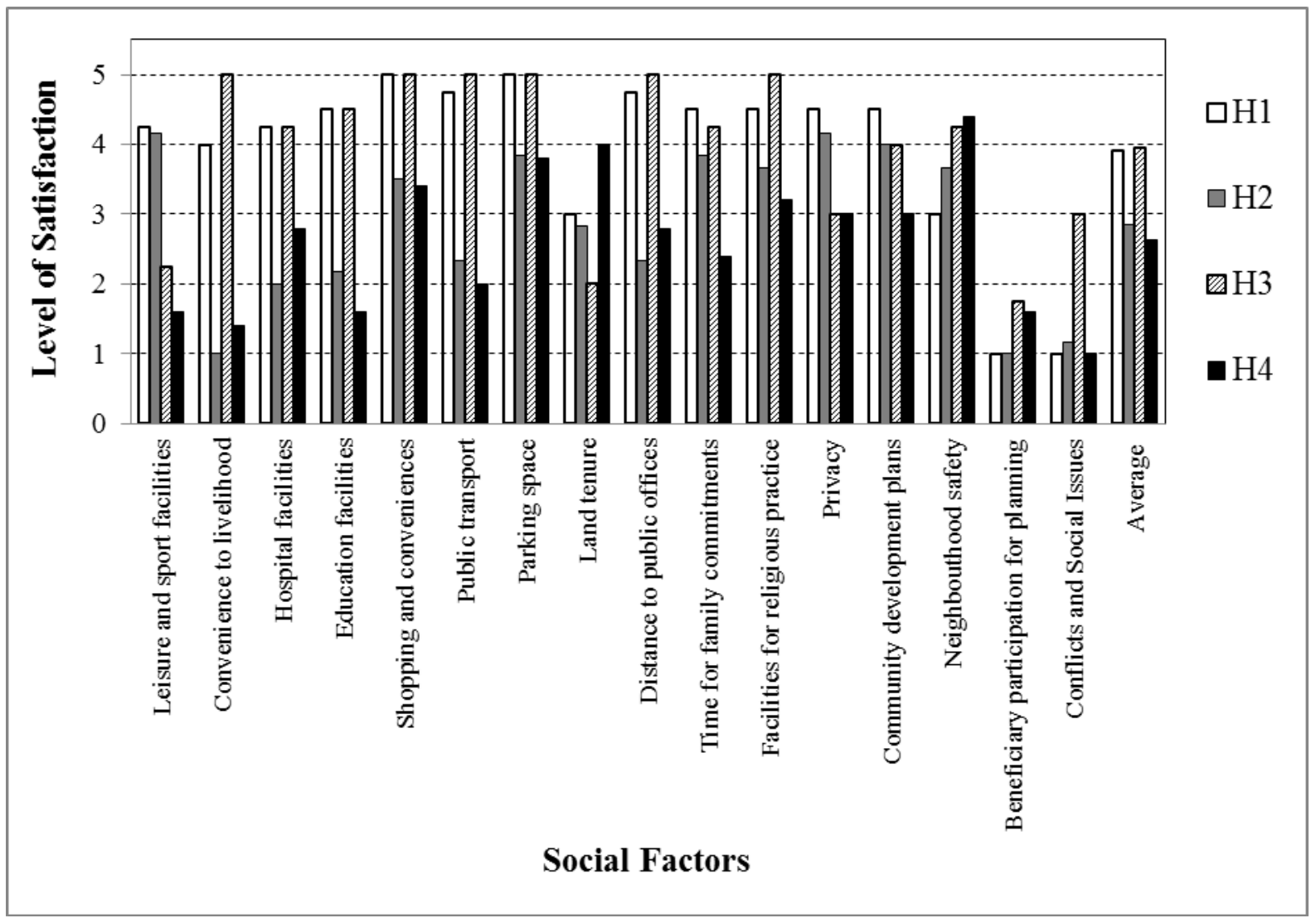

Figure 7. Level of satisfaction due to social factors in the Hambantota District

(Level of satisfaction: 1 - Strongly dissatisfied, 2 - Dissatisfied, 3 - Neutral, 4 - Satisfied, 5 - Strongly satisfied)

The level of satisfaction expressed by the occupants of the sites in the Hambantota District (Figure 7) for beneficiary participation for planning and conflicts and social issues has been very low. The majority of occupants in sites $\mathrm{H} 1$ and $\mathrm{H} 3$ are satisfied with most of the social aspects, other than the factors mentioned above. Site H2, where the majority of the householders are fishery-related, the occupants stated that they are strongly dissatisfied with the location which has adversely affected their convenience to livelihood. The reasons are very similar to those mentioned for G1 and G2, including lack of public transportation facilities. Occupants of the site H4 expressed their strong dissatisfaction or dissatisfied about most of the social factors, of which important factors were the lack of leisure and sports facilities, hospital facilities, education facilities, public transportation, distance to public offices, etc. Privacy was not a major issue, probably due to larger land plot sizes and better 
siting of houses within the project area. The prevalence of conflicts and social issues were again similar to those recorded for Galle and Matara.

\subsection{Level of Satisfaction: Environment Factors}

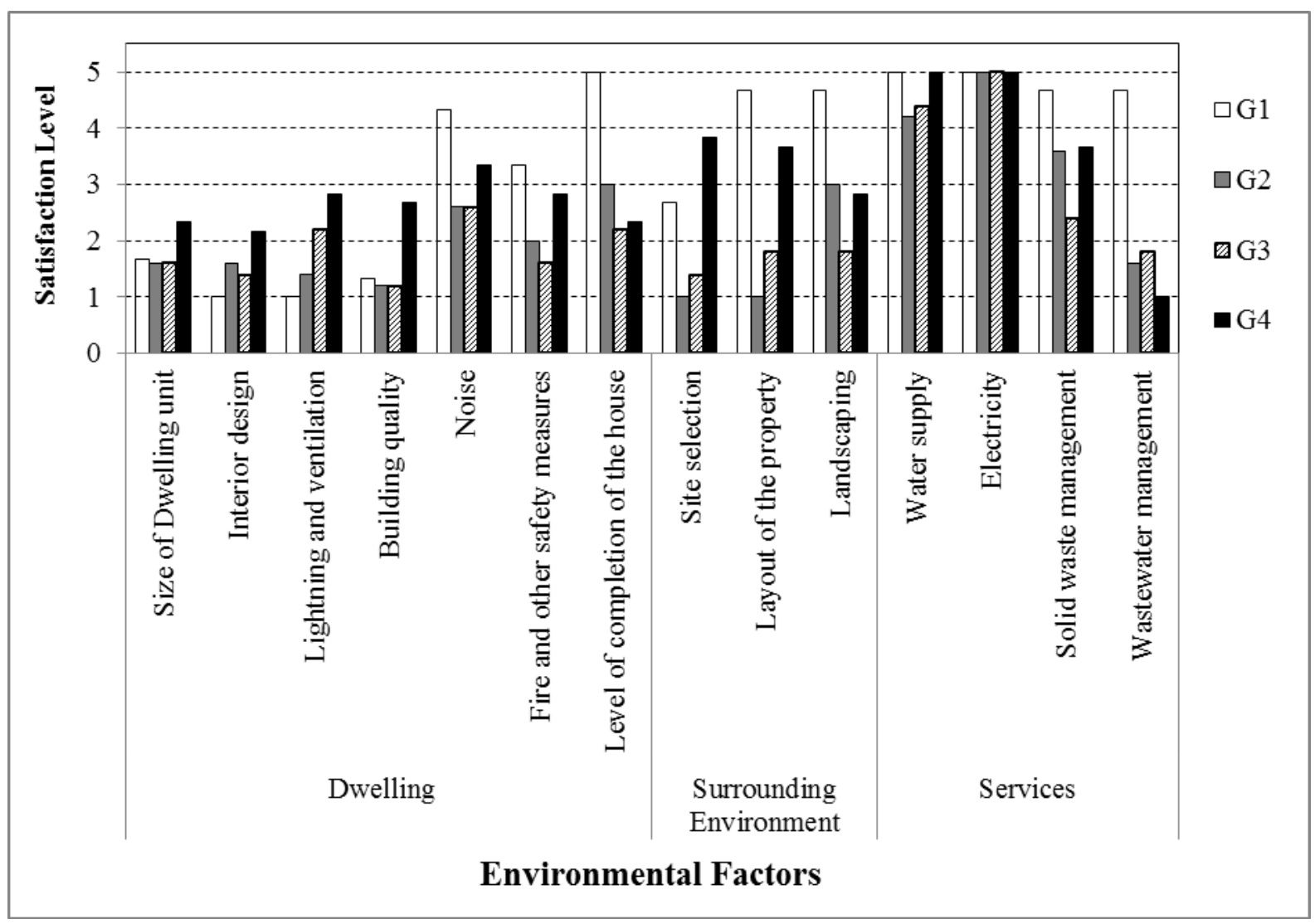

Figure 8. Level of satisfaction due to environmental factors in the Galle District

(Level of satisfaction: 1 - Strongly dissatisfied, 2 - Dissatisfied, 3 - Neutral, 4 - Satisfied, 5 - Strongly satisfied)

All the respondents in Galle and Matara sites were unsatisfied due to the small dwelling size of the houses, although the minimum requirements specified in the Guidelines (size $>46.5$ $\mathrm{m}^{2}$ ) have been observed (Figures $8 \& 9$ ). Average floor area per occupant was the least in Matara $\left(8.8 \mathrm{~m}^{2}\right)$ and highest in Galle $\left(11.3 \mathrm{~m}^{2}\right)$, whereas it was $10.5 \mathrm{~m}^{2}$ in Hambantota. Houses with same floor area were provided for resettlers irrespective of the family size. Resettlers in Hambantota were satisfied with the size of the house (Figure 10) because they have been able to build extensions to their housing units as they have received larger land plots $(15-20$ perch) than Galle and Matara, who receive about $6-8$ perch of land. 


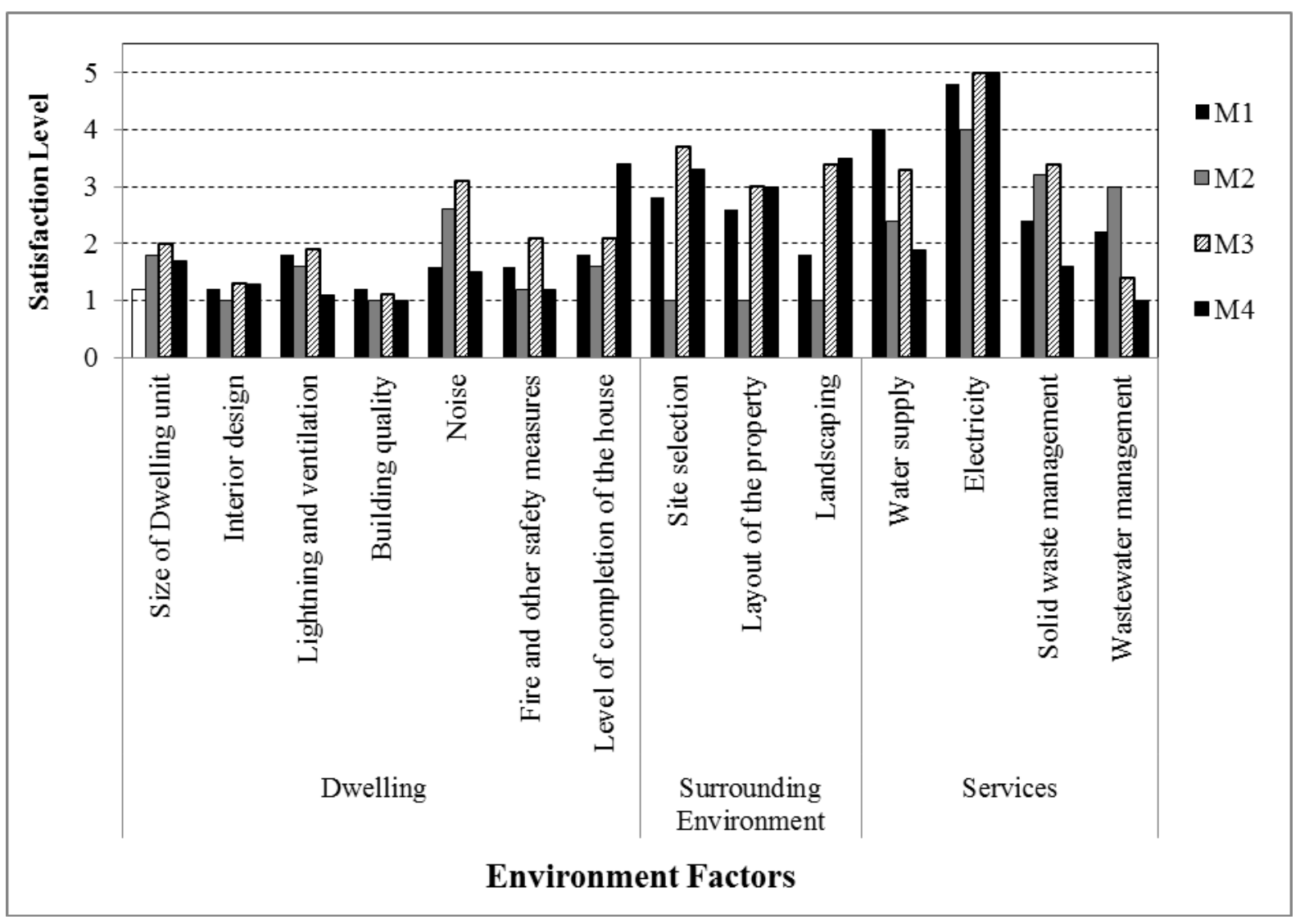

Figure 9. Level of satisfaction due to environmental factors in the Matara District

(Level of satisfaction: 1 - Strongly dissatisfied, 2 - Dissatisfied, 3 - Neutral, 4 - Satisfied, 5 - Strongly satisfied)

The majority of resettlers in at least ten sites were dissatisfied with the interior design, which has been decided by the donors' requirements or funds availability. In most cases, planning and designs have been finalised by persons who have never visited the sites or without paying proper attention to the real ground situation. The orientation of houses, designs of kitchens and toilets/bathrooms were major concerns. Proper ventilation for toilets, kitchens and interior spaces of houses has not been provided in 10 out of the 12 sites. It was common to observe new constructions and extension to houses with new kitchens and toilets built outside the houses as detached units. Natural lighting and ventilation is very poor, for most of the houses in Galle and Matara, due to improper orientation and houses being constructed very close to each other.

Almost all the occupants were dissatisfied with the quality of construction, and material used in construction. Fractures of walls, floors and paved surfaces were common. The collapse of roofs was observed in every site at Matara. Poor quality timber, roofing material, doors and windows, poor quality finishes and inferior quality fixtures and fillings were noted at almost all the houses. 


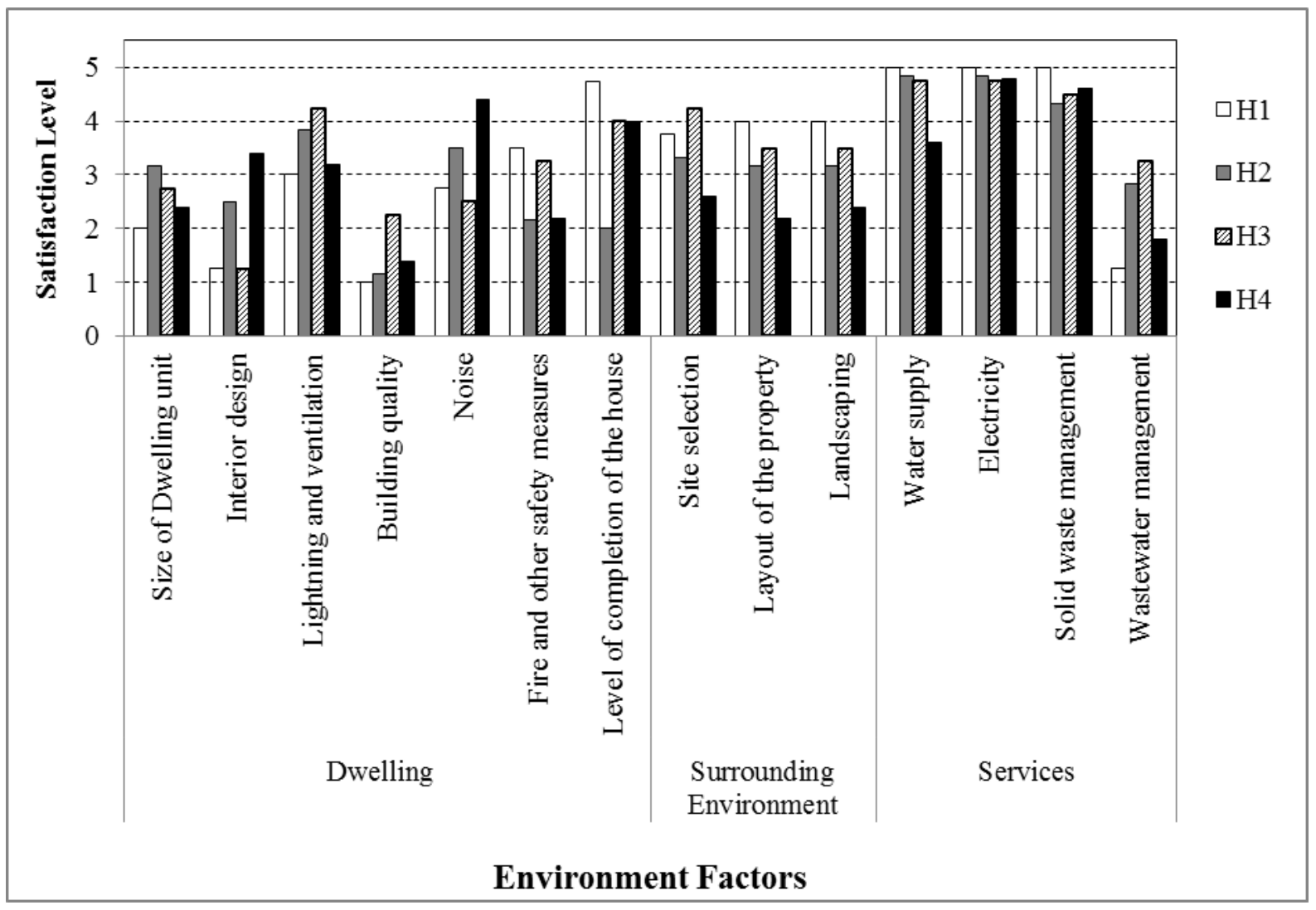

Figure 10. Level of satisfaction due to environmental factors in the Hambantota District (Level of satisfaction: 1 - Strongly dissatisfied, 2 - Dissatisfied, 3 - Neutral, 4 - Satisfied, 5 - Strongly satisfied)

Occupants of three sites at Matara (M1, M2 and M3) reported that the houses were not complete at the time of resettlement. It was noted that toilets and bathrooms were incomplete at site M2 and H2. According to the community leaders, the reason was the lack of funds allocated for construction, probably due to the escalation of costs with time.

Site selection was another factor of which most of the resettlers expressed their dissatisfaction. The affected people lived close to the coast before the tsunami. No reconstruction of damaged houses was allowed due to the newly-enacted buffer zone policy, and therefore the affected people had to be resettled in some other locations. Galle and Matara are highly populated urban areas, and land availability for new settlements was very limited. As observed during the survey all the resettlers are unsatisfied with the site selection except for resettlements located close to their previous settlements (sites G4, M4 and H3). Water logging and frequent flooding in sites which were located in low-lying areas; difficult access due to undulating terrain, unstable slopes and erosion of the roads and open areas in sites which were located in hilly areas were common problems that were observed. Landscaping, provision of common areas for recreation and public purposes have not been 
considered at all at the planning stages probably due to the scarcity of land, except for sites G1 and H1.

According to TAFREN guidelines, implementing agencies (usually the UDA or the local authority) were required to provide infrastructure connections and internal roads within each site, while the government held the responsibility for providing external roads, water, electricity and wastewater connection facilities up to the site boundary. Upon completion of construction, the responsibility for maintaining common areas, street lighting, internal roads, and garbage collection was the responsibility of local councils. Almost all the sites had pipe-borne water and electricity. In 8 of the 12 sites, water is supplied for only a few hours each day, and due to the limited supply, conflicts and disputes arise. In most of the sites, water is first provided to underground reservoirs, which is then pumped to rooftop tanks; however, frequent breakdown of the pumps is common. Water is supplied less frequently during the dry season (e.g., at M3, H3 and H4 once per three days). There were complaints about poor water quality in Matara sites. Two sites in Galle and Hambantota and all the sites in Matara had no proper solid waste collection system and collection by the local authorities was very erratic. At two sites in Hambantota ( $\mathrm{H} 3$ and $\mathrm{H} 4)$, resettlers have their own space to manage biodegradable solid waste within their gardens. Most of the time people just dump their solid waste along roadsides or nearby unoccupied lands that create severe hygiene issues, and in some cases lead to severe social conflicts.

Wastewater management is more critical than the solid waste management in most of the resettlement sites. For most of the houses, standard sized septic tank and soakage pits have been constructed without considering household size as a design parameter. Consequently, in houses where larger families lived, the septic tanks often overflowed during the rainy season due to smaller sizes, which is a potential public health hazard. It was noted in some sites that no soakage pits have been provided, or water would not be soaked due to waterlogged conditions and the wastewater from the septic tanks overflow into the garden especially during the rainy season. This has resulted in very unhygienic conditions, especially for small children and promoting breeding of mosquitoes and other insects, which frequently leads to frequent conflicts among the neighbours. With overflowing septic tanks and blocked open drains, the living in these housing schemes often becomes very unpleasant and unhealthy.

\section{Discussion}

It is widely acknowledged that displacement causes severe socio-economic and environmental stresses that translate themselves into physiological, psychological, socio-cultural, economic and ecological damage (Cernea, 1995, 2000; Manatunge et al., 2009; Takesada et al., 2008; Manatunge et al., 2013 a, b). Moreover, it is generally accepted that by expanding resettlement objectives beyond merely aiming to improve the standards of living of people, it would be possible to offset these disabilities (Cernea, 1995, 2000). It is important to understand that displacement is a multidimensional phenomenon that physical relocation is only one of the most significant outcomes (Bartolomé et al., 2000). There are some perspectives that have to be considered in planning, implementation and practising resettlement housing projects. 
In the early 1980s, Scudder and Colson (1982) proposed a four-stage model of how people and socio-cultural systems respond to resettlement: (i) recruitment phase, where policy-makers and/or developers attempt to formulate resettlement plans, often without informing the beneficiaries; (ii) transition phase, where people learn about their future resettlement, which heightens the level of stress experienced; (iii) phase in which the resettlers begin the process of rebuilding their lives and social networks; and (iv) handing over or incorporation phase, where handing over of assets and community leadership to a second generation of residents that identifies with and feels at home in the community. Once this stage has been achieved, resettlement is deemed a success (Scudder \& Colson, 1982).

As identified by Cernea $(1995,2000)$ the most widespread effect of involuntary resettlement is the impoverishment of considerable people, as identified in this study, landlessness, joblessness due to the inconvenience to livelihood, homelessness as most of the resettlers does not feel the houses given to them as 'homes', marginalization, loss of access to common property and community disarticulation.

One of the biggest challenges after a disaster is how resettlement housing activities should be embarked on. Different reconstruction strategies result in different outcomes. Informed decisions should be taken on how the needs of the affected persons who will be resettled in new sites be addressed and make them satisfied of the assets that they receive. Proper planning and subsequent implementation should take factors into consideration that are perceived to be sensitive. The decisions made related to reconstruction and recovery strategies should reflect the planning guidelines to be adopted. Identifying the most suitable and applicable strategy for each situation is importance in providing better support to the beneficiaries and to avoid possible future vulnerabilities. Based on the observations of this study, several aspects are discussed below that are relevant in considering the long term satisfaction of the resettlers.

\subsection{Improper Planning and Coordination of the Resettlement Process}

There were no planning guidelines, policies or regulations existed in Sri Lanka at the time of when the tsunami disaster occurred in December 2004, which could be readily adopted for the administration of disaster-related resettlement programmes. As a consequence of the tsunami, massive influxes of funds were flown into the country, together with assistance in kind. Although the government institutions responded strongly in the initial emergency phase, they had no capacity to coordinate the rehabilitation affairs properly. Moreover, there were no effective command structures and communication channels, and officials and donors lacked guidance on matters that required centralised decision-making and were not sufficiently informed of government policy and policy changes, leading to the inconsistent application of regulations (Shaw \& Ahmed, 2010). The government agencies (notably, the UDA) were under-resourced at the time of the tsunami, and thus they were not properly equipped to manage the immensely increased workloads. There were notable deficiencies of capacity at governmental agencies, especially at the local level regardless of their willingness to undertake more work for coordinating and guiding the resettlement process (ADB, 2005). 
Although the government enacted planning guidelines for disaster housing reconstruction (such as TAFREN, UDA and NHDA Guidelines), only a few donors sought planning approvals before implementation. The under-resourced government agencies such as the UDA and THRU were under immense pressure to expedite implementation and allowed the donors to commence the projects without paying any attention to prior approval. Subsequently, the absence of planning documentations, proper implementing guidelines, and non-existence of mechanisms for grievance redress caused significant problems for householders. With mounting pressure building up from the stakeholders, the government officials tried to obtain updates of implementation plans from the donor agencies. However, in most cases this failed because many of the donors had already left upon handing over the houses to beneficiaries.

\subsection{Lack of Beneficiary Participation in Planning}

The responsibility for selection of contractors for building housing units was assigned to individual donors. The government agencies (TAFREN (and later RADA), UDA, local authorities, etc.) retained the responsibilities such as policy formulation, coordination of resettlement process and monitoring. It was clearly evident from this study that no beneficiary participation or consultations have been made during planning and/or implementation stages, one of the factors with which the respondents are strongly unsatisfied. This exclusion of local beneficiary participation in planning has resulted in the improper planning of both exterior and interior designs, not paying proper attention to local natural environmental, cultural and socio-economic diversity, which are the primary factors that have trickled down to cause many other related problems (as listed above). Transfer of houses demands more planning and coordinated effort than merely distribution of the assets, as resettlement sites need appropriate provision and setting up of infrastructure and other facilities, to ensure long-time sustainability and acceptance of the property by the beneficiaries (Gunawardena \& Wickramasinghe, 2010).

Many past studies on resettlement housing provide much evidence related to inappropriate designs that result from insufficient attention paid to cultural needs and local conditions (Barenstein 2012, Takesada et al., 2008; Manatunge et al., 2013 a, b). The pressure to achieve quick results usually compromises the quality of construction and limits the opportunities for community consultative processes ['tyranny of the urgent', refer Delaney \& Shrader (2000)]. The planners in such instances overlook beneficiary participation aiming at accelerated reconstruction programs, and they consider such time-consuming consultations as unnecessary, which result in houses which do not match the expectations and needs of beneficiaries and their culture. Seneviratne (2015) reported that construction commenced even before selection of beneficiaries in some of the sites in Galle, Matara and Hambantota thereby overlooking the prospects for beneficiary participation in needs assessment and subsequent planning and design. When site layouts and housing designs do not match the expectations of the beneficiaries in terms of comfort, building material and construction quality and sensitivity to cultural and community practices, the prospective benefitiaries respond in a multitude of ways: refusing to accept or occupy the house, attempting to modify it or and sell or rent to outsiders (Barakat 2003; Ahamed \& Shaw, 2010). 


\subsection{Improper Site Selection}

The sites selected for the resettlement schemes were public land. However, scarcity of land was one of the significant constraints, especially in the three districts that the present study was conducted. In addition, the planners had to comply with the resettlement planning guidelines (TAFREN) for selection of relocation sites which emphasised that the resettlement sites be located as close as possible to original settlements with the intention of keeping communities intact. This was a challenge for the projects proposed in Galle and Matara, given the situation that areas close to the coast in the two districts are already densely populated.

In the face of scarcity of proper land for housing construction, some of the selected sites were located in waterlogged and low-lying areas or undulating terrain, which are not very suitable for housing construction. Although the District Administration was responsible for site selection and land allocation, they lacked the qualified technical staff to assess suitability. By the time when the expert teams from the University of Moratuwa conducted comprehensive assessments of the appropriateness of the sites (UoM, 2006), construction works were underway in most of the sites, and alternative site selection was not an option. However, these studies highlighted high levels of erosion, unstable slopes, water logging and water table fluctuations, difficulty in providing proper access roads, infrastructure and services as deficiencies in site selection for many of the sites in Galle, Matara and Hambantota. According to recent observations covering more than 50 locations in these three districts by Seneviratne (2015), most of the occupants of the housing sites which were previously identified as 'problematic' (UoM, 2006) face severe difficulties at present due to improper site selection, eventually forcing them to either sell or abandon the houses.

Acquisition of private land was an option available in districts where public land was scarce, which have been made after proper site selection (personal communications with resettlers in Matara). Some of the donors dealt directly with landowners to minimise delays in transferring of legal titles or managed to obtain suitable sites in instances where government land was deemed unsuitable. Occupants of such housing schemes seem to be happier with what they have received as compensation.

\subsection{Disparities of the Physical Assets Distributed among Sites and Deficiencies in Planning Settlements and Houses}

Some of the resettlement housing schemes located in the same location have been sub-divided into smaller projects to match the funding availability of different donor agencies. In most cases, such sub-projects have been planned, designed and implemented as separate projects which had different features, commensurate with the amount of funding available and donor requirements. The only obligation of the donor was to meet the minimum standard specification (MSS) issued by the government: a minimum floor area of $46.5 \mathrm{~m}^{2}$ with two bedrooms, a living room, kitchen, and toilet, and equipped with electricity, running water, sanitation and drainage facilities (TAFREN, 2005). In certain cases, no proper attention had been paid to interior design, sizing and interconnection of functional spaces, natural ventilation and lighting, providing services, and even construction materials used. 
The UDA and TAFREN guidelines specified mandatory minimum requirements for house size, plot size, room requirement and sizes, land coverage for roads, drains, common areas, parking and infrastructure.

Two minimum plot sizes were specified by the UDA for plots with and without pipe-borne water and sewerage (152 and $506 \mathrm{~m}^{2}$ respectively). Within municipal and urban council limits, provision of pipe-borne water and sewerage is regarded as a statutory requirement, and therefore the land plots for urban areas was the lower of the two sizes. It is obvious that the application of the plot size as specified by the guidelines in the sites included in this study is related to land availability rather than complying with the guidelines. None of the sites, in the three districts, had sewerage connections. However, the plot allocation has been the lower of the two sizes. The larger land plot sizes were allocated for sites located in rural areas with the intention of installing a septic tank /ground soakage systems and a shallow well for the use of each house. The sites which experienced high water table and poor drainage especially during rainy season encountered difficulties in on-site wastewater disposal using the soakage tank. Out of the 12 sites, eight sites experienced this situation, and overflowing septic systems was a common problem, which had led to poor hygienic conditions, and conflicts among the neighbouring houses.

All the houses that were included in this study complied with the minimum floor area requirement. However, all the houses in each site used a standard housing plan without taking the household size into account, needs of the occupants or any environmental factors such as natural lighting, ventilation and orientation of other houses, which is commonly referred to as a 'one-size-fits-all approach' (Shaw \& Ahmed, 2010). The stipulated minimum floor area (46.5 $\mathrm{m}^{2}$ ) in Sri Lanka can comfortably accommodate a small family according to prevailing local standards but provides cramped living conditions for larger households (Shaw \& Ahmed, 2010). However, the majority of the occupants in both Galle and Matara expressed dissatisfaction regarding the size of the dwelling unit and interior design. All the houses included a kitchen and latrine, both as attached units, as specified in the UDA guidelines. It was observed, in most cases, that room sizes and wall heights did not comply with the guidelines and the majority of the resettlers were dissatisfied with the interior design (10 out of the 12 sites). Kitchens and toilets did not have proper ventilation suitable for cooking using firewood, which is used by most households, which have forced them to do alterations to original constructions. The guideline regarding the allocation of land for parking spaces, roads, drains and other infrastructure have not been observed in sites close to urban areas due to land scarcity. Proper landscaping was also not seen in two sites in Galle and Matara each. The layout of the houses was another factor that the occupants were not satisfied with, especially closeness of the houses to each other, and unacceptable orientation of rows of houses which have affected the privacy of the occupants severely.

Allocation of space for communal and recreational areas such as community centres, playgrounds, parks and meeting places has not received proper attention, probably due to the absence of guidelines for such allocation. None of the sites covered in this study has proper allocations for such common purposes, which the occupants are dissatisfied. The majority of the donors have primarily focused their efforts in providing houses to beneficiaries, and 
overlooking the need to have proper public and common spaces. Provision of public spaces within the site, except for roads and drainage, and incorporating any other features such as spacing between houses, elements for landscaping were at the discretion of the donor agency. Seneviratne (2015) also reports that most of the tsunami resettlement housing schemes in Sri Lanka have not considered providing sufficient space for common purposes.

\subsection{Escalation of Prices and Quality of Construction}

The sharp boom in the construction industry soon after the tsunami led to increased material and labour costs, and there was a consensus among the donor community and government officials that there was a widening disparity in funding availability and construction costs. The donor funding and estimates were typically based on the costs and prices that prevailed in early 2005, i.e., the immediate aftermath of the tsunami. The escalation in construction costs due to shortages of land, labour and materials was not unforeseen, and by the end of 2006 , costs had increased by more than $80 \%$ (Weerakoon et al., 2007). Some of the implementing agencies requested additional aid from donor agencies to cover the cost overruns; however, some others resorted to reducing the number of houses they were to build and/or compromised the cost with reduced quality (Shaw \& Ahmed, 2010). The donors had considerable flexibility in adopting their construction methods to match the budgetary allocations since the housing guidelines imposed by the UDA were not mandatory for construction methods or materials. Seneviratne (2015) reported that a most of the donors did not comply with these non-mandatory requirements as there were no proper monitoring mechanisms by the UDA or the NHDA. Moreover, it was noted that some contractors working for the donors employed unskilled labor for construction, used locally-sourced inferior quality construction material and delayed the construction progress. Settlement of sub-structures, cracking of walls and floors, poor quality finishes and fittings, unsuitable material for walls, floors and roofs were commonly observed at many resettlement sites in Sri Lanka (Seneviratne, 2015). In contrast to the owner-driven houses, contractor-driven houses (that were focused in this study), resulted in significant numbers of homeowners being unsatisfied with the quality of the materials used and the quality of construction. Such factors invariably lead to dissatisfaction among the beneficiaries.

\section{Conclusions}

Based on the observations of this study, it can be concluded that despite the availability of abundant funding, the opportunities to plan, design and implement sustainable community-responsive resettlement programmes for tsunami affected households were essentially missed. Design and construction of houses, which is the key focus of any resettlement programme, the outcome has been disappointing. Overall, it can be noted that the occupants in the resettled communities included in the present study are not satisfied in the long-term due to many physical, environmental and socio-economic factors.

In consultation with the aid community and other stakeholders, it is important to establish a coherent and a practical set of housing and resettlement guidelines, as part of disaster preparedness, defining the responsibilities of all the stakeholders. Special focus should be paid to setting out the roles of each, with clearly differentiating between government and 
non-government agencies. Proper implementation of guidelines for site selection and housing planning and construction should be formulated with proper monitoring mechanisms in place. Reconstruction of houses has to be complemented with a long-term system of support reflecting the needs of the beneficiaries. Better layout plans with better spacing between housing units, appropriately sized functional spaces in the dwelling unit, provision of common space, good quality of construction have to be considered from the earliest stage of a reconstruction programme.

The responsibility of proper planning, design and implementation must be shared between both the government agencies and the donor community alike. Providing resettlement housing should be viewed as a core planning exercise, involving all the stakeholders, so as to ensure that different aspects are integrated so that the housing schemes are livable places for recipients. This is in contrast to merely providing permanent houses to affected communities and then deciding about the provision of other facilities where and when it is needed. More importantly, it should be noted that beneficiary participation would positively contribute towards the formulation of more acceptable housing schemes so that the occupants would ultimately have a feeling that they live in "homes" not just "houses".

\section{Acknowledgements}

This study was funded by the Mitsui \& Co., Ltd, Environmental Fund and the Graduate School of Frontier Sciences, the University of Tokyo. Support was also provided by the Reconstruction Agency of the Japanese Government through the Hirono Town in the Fukushima Prefecture.

\section{References}

Asian Development Bank. (2005). Sri Lanka: Post-Tsunami Recovery Program: Preliminary Damage and Needs Assessment. Manila: Asian Development Bank.

Barakat, S. (2003). Housing Reconstruction after Conflict and Disaster.Humanitarian Policy Group, Network Papers 43, 1-40.

Bartolomé, L. J., De Wet, C., Mander, H., \& Nagraj, V. K. (2000). Displacement, resettlement, rehabilitation, reparation and development. WCD Thematic Review, 1. The World Commission of Dams.

Benson, C., \& Twigg, J. (2007). Tools for Mainstreaming Disaster Risk Reduction: Guidance Notes for Development Organizations. Geneva: International Federation of Red Cross and Red Crescent Societies.

Bilau, A. A., Witt, E., \& Lill, I. (2015). A Framework for Managing Post-disaster Housing Reconstruction, Procedia Economics and Finance, 21, 313-320

Birkmann, J., \& Fernando, N. (2008).Measuring revealed and emergent vulnerabilities of coastal communities to tsunami in Sri Lanka.Disasters, 32(1), 82-104.

Cernea, M. (2000). Risks, safeguards, and reconstruction: A model for population displacement and resettlement. Economic and Political Weekly, 35(41), 3659-3678. 


\section{Macrothink}

Cernea, M. (1995). Understanding and preventing impoverishment from displacement: Reflections on the state of knowledge. Journal of Refugee Studies, 8(3), 245-264.

Davidson, C. H., Johnson, C., Lizarralde, G., Dikmen, N., \& Sliwinski, A. (2007).Truths and Myths about Community Participation in Post-Disaster Housing Projects.Habitat International, 31(1), 100-115

Delaney, P., \& Shrader, E. (2000). Gender and Post-Disaster Reconstruction: The Case of Hurricane Mitch in Honduras and Nicaragua. Draft Report. Washington, DC: The World Bank.

Dias, N. T., Keraminiyage, K., \& De Silva, K. K. (2016). Long-term satisfaction of post disaster resettled communities: The case of post tsunami - Sri Lanka. Disaster Prevention and Management: An International Journal, 25(5), 581-594.

Duyne Barenstein, J. (2012). Towards sustainable post-disaster housing and building technologies. Issues and challenges with special reference to India. In: J.C. Bolay, M. Schmid, G. Tejada \& E. Hazboun (Eds.), Technologies and Innovations for Development: Scientific Cooperation for a Sustainable Future. Paris: Springer-Verlag, pp. 102-34.

FEMA (2017).Social Impacts of Disaster - Federal Emergency Management Agency. Retrieved from https://training.fema.gov/hiedu/docs/fem/chapter $\% 206 \% 20 \% 20$ hazard $\% 20$ (accessed on 7 January 2017).

Grewal, M. K. (2006). Approaches to Equity in Post-Tsunami Assistance. Sri Lanka: A Case Study. Department of International Development, London and Office of the UN Secretary General's Special Envoy for Tsunami Recovery. Retrieved from http://www.alnap.org/pool/files/ApproachestoEquity.pdf (accessed on 6 October 2016).

Gunawardena, A., \& Wickramasinghe, K. (2010). Targeting and Distribution of Post-Tsunami Aid in Sri Lanka: A Critical Appraisal, SANDEE Working Paper No. 55 - 10, Kathmandu: South Asian Network for Development and Environmental Economics (SANDEE).

Jayasuriya, S., Steele, P., \& Weerakoon, D. (2006). Post-tsunami recovery: issues and challenges in Sri Lanka, ADBI Research Paper Series No. 71.Tokyo: Asian Development Bank Institute.

Kusky, T. M. (2003). Geological hazards: A Sourcebook, Greenwood Press, Westport, CT.

Manatunge, J., Nakayama, M., \& Contreras-Moreno, N. (2001).Securing ownership in aquaculture development by alternative technology: Acase study of the Saguling Reservoir, West Java. International Journal of Water Resources Development, 17(4), 61-631.

Manatunge, J., Takesada, N., Miyata, S., \& Herath, L. I. (2009). Livelihood rebuilding of dam-affected communities: Case studies from Sri Lanka and Indonesia. International Journal of Water Resources Development, 25(3), 479-489. 


\section{Ml Macrothink}

Journal of Asian Development

ISSN 2377-9594 2017, Vol. 3, No. 1

Manatunge, J., \& Takesada, N. (2013a). Long-term perceptions of project-affected persons: A case study of the Kotmale Dam in Sri Lanka, International Journal of Water Resources Development, 29(1), 87-100.

Manatunge, J., \& Takesada, N. (2013b). Long-term perceptions of project-affected persons: A case study of the Kotmale Dam in Sri Lanka. In: M. Nakayama \& R. Fujikura (Eds.), Restoring Communities Resettled After Dam Construction in Asia (Routledge Special Issues on Water Policy and Governance), Oxford: Taylor and Francis, pp. 78-89.

Miyata, S., \& Manatunge, J. (2004). Knowledge sharing and other decision factors influencing adoption of aquaculture in Indonesia. International Journal of Water Resources Development, 20(4), 523-536.

Mubarak, K. (2007). Analyzing Post-Tsunami Livelihoods Recovery: the case of Masons in Polhena Village, Sri Lanka, SSEE Research Paper No. 2, Melbourne: University of Melbourne.

Mulligan, M., \& Shaw, J. (2007). What the world can learn from Sri Lanka's post-tsunami experiences, International Journal of Asia Pacific Studies, 3(2), 65-91.

NHDA. (National Housing Development Authority). (2005).Guidelines for housing development in coastal Sri Lanka, Ministry of Housing and Construction, Colombo.

Oliver-Smith, A. (2007). Successes and failures in post-disaster resettlement, Disasters, 15(1), $12-23$.

Ophiyandri, T. (2011). Community-based post-disaster housing reconstruction: examples from Indonesia, In: Amarathunga, D. and Haigh, R. (Eds.), Post-Disaster Reconstruction of the Built Environment: Rebuilding for Resilience. Retrieved from http://onlinelibrary.wiley.com/book/10. 1002/9781444344943.

Perera, T., Weerasoori, I., \& Karunarathne, H. (2013). An evaluation of success and failures in Hambantota, Siribopura Resettlement Housing Program: Lessons Learned, Sri Lanka Journal of Real Estate, 6, 1-15.

Ratnayake, R. M. G. D., \& Rameezdeen R.(2008). A comparative study of donor driven vs. owner driven post disaster housing reconstruction. Proceedings of the CIB International Conference on Building Education and Research, held from 11-15 February, 2008 at Kandalama, Sri Lanka. pp. 192.

Reconstruction and Development Authority (RADA) (2007). Mid-year Review: Post-tsunami Recovery and Reconstruction, RADA, Colombo.

Scudder, T., \& Colson, E. (1982). From welfare to development: A conceptual framework for the analysis of dislocated people, In: A. Hansen \& A. Oliver-Smith (Eds.), Involuntary Migration and Resettlement: The problems and responses of dislocated people, 267-87. Boulder, USA: Westview Press. 


\section{Macrothink}

Journal of Asian Development

ISSN 2377-9594 2017, Vol. 3, No. 1

Seneviratne, A. D. (2015). Comprehensive guideline for sustainable involuntary resettlement - special case study on problematic tsunami resettlement sites in Galle district, MSc Thesis submitted to University of Moratuwa, Sri Lanka.

Shaw, J., \& Ahmed, I. (2010). Design and Delivery of Post-disaster Housing Resettlement Programs: Case Studies from Sri Lanka and India. Report 6. Monash Asia Institute, Melbourne: Monash University.

TAFREN. (2005). Housing and township development: Assistance policy and implementation guidelines. Colombo: TAFREN.

Takesada, N., Manatunge, J., \& Herath, I. L. (2008). Resettler choices and long-term consequences of involuntary resettlement caused by construction of Kotmale Dam in Sri Lanka. Lake \& Reservoirs Management, 13(3), 245-254.

Thiruppugazh, V. (2011). When people are involved. In: M. Aquilino (Ed.), Beyond Shelter. Architecture and Human Dignity. New York: Metropolis Press, 70-82.

UoM. (2006). Rapid Environmental Assessment (REA) on Tsunami Permanent Housing Sites in Sri Lanka. Unpublished Report, Moratuwa: University of Moratuwa, Sri Lanka.

Uyangoda, J. (2005). Post-Tsunami Recovery in Sri Lanka, Polity, 2(3). Social Scientists' Association of Sri Lanka, Colombo.

Weerakoon, D., Jayasuriya, S., Arunatilake, N., \& Steele, P. (2007). Economic Challenges of Post-Tsunami Reconstruction in Sri Lanka. Colombo: Institute of Policy Studies.

\section{Copyright Disclaimer}

Copyright for this article is retained by the author(s), with first publication rights granted to the journal.

This is an open-access article distributed under the terms and conditions of the Creative Commons Attribution license (http://creativecommons.org/licenses/by/3.0/). 